\title{
Bats Increase the Number of Cultivable Airborne Fungi in the "Nietoperek" Bat Reserve in Western Poland
}

\author{
Tomasz Kokurewicz $^{1}$ - Rafal Ogórek ${ }^{2} \cdot$ Wojciech Pusz ${ }^{3} \cdot$ Krzysztof Matkowski $^{3}$
}

Received: 11 January 2016 / Accepted: 29 March 2016 / Published online: 15 April 2016

(C) The Author(s) 2016. This article is published with open access at Springerlink.com

\begin{abstract}
The "Nietoperek" bat reserve located in Western Poland is one of the largest bat hibernation sites in the European Union with nearly 38,000 bats from 12 species. Nietoperek is part of a built underground fortification system from WWII. The aims of the study were (1) to determine the fungal species composition and changes during hibernation season in relation to bat number and microclimatic conditions and (2) evaluate the potential threat of fungi for bat assemblages and humans visiting the complex. Airborne fungi were collected in the beginning, middle and end of hibernation period (9 November 2013 and 17 January and 15 March 2014) in 12 study sites, one outside and 11 inside the complex. Ambient temperature $\left(T_{\mathrm{a}}\right)$ and relative humidity $(\mathrm{RH})$ were measured by the use of data loggers, and species composition of bats was recorded from the study sites. The collision method (Air Ideal 3P) sampler was used to detect 34 species of airborne fungi including Pseudogymnoascus destructans (Pd). The density of airborne fungi isolated from the outdoor air samples varied from 102 to $242 \mathrm{CFU} / 1 \mathrm{~m}^{3}$ of air and from 12 to $1198 \mathrm{CFU}$ in the underground air samples. There was a positive relationship between number of bats and the concentration of fungi. The concentration of airborne
\end{abstract}

Rafał Ogórek

rafal-ogorek@wp.pl

1 Department of Vertebrate Ecology and Paleontology, Institute of Biology, Wrocław University of Environmental and Life Sciences, Kożuchowska 5b, 51-631 Wrocław, Poland

2 Department of Genetics, Institute of Genetics and Microbiology, University of Wrocław, Przybyszewskiego 63/77, 51-148 Wrocław, Poland

3 Department of Plant Protection, Wrocław University of Environmental and Life Sciences, pl. Grunwaldzki 24a, 50-363 Wrocław, Poland fungi increased with the increase of bats number. Analysis of other possible ways of spore transport to the underground indicated that the number of bats was the primary factor determining the number of fungal spores in that hibernation site. Microclimatic conditions where $\mathrm{Pd}$ was found (median $8.7^{\circ} \mathrm{C}$, min-max $6.1-9.9^{\circ} \mathrm{C}$ and $100 \%$, min-max $77.5-$ $100.0 \%$ ) were preferred by hibernating Myotis myotis and Myotis daubentonii; therefore, these species are most probably especially prone to infection by this fungi species. The spores of fungi found in the underground can be pathogenic for humans and animals, especially for immunocompromised persons, even though their concentrations did not exceed limits and norms established as dangerous for human health. In addition, we showed for the first time that the air in bats hibernation sites can be a reservoir of Pd. Therefore, further study in other underground environments and wintering bats is necessary to find out more about the potential threat of airborne fungi to bats and public health.

Keywords Airborne fungi · Bats · "Nietoperek" bat reserve . Pseudogymnoascus destructans

\section{Introduction}

Specific microclimatic conditions in underground sites used by bats for hibernation are one of the most inhospitable habitats for microbial life due to low temperatures and scarcity of organic matter [1-4]. Stable and low temperature ca. $10{ }^{\circ} \mathrm{C}$ is generally the only factor beneficial to development of psychrophilic microorganisms, e.g. for Pseudogymnoascus destructans $(\mathrm{Pd})$ having optimal growth temperatures between 12.5 and $15.8{ }^{\circ} \mathrm{C}$ and the upper critical temperature between 19.0 and $19.8{ }^{\circ} \mathrm{C}$ [5]. Therefore, fungi are commonly observed growing on organic matter in any underground 
environments but are present regularly as spores, carried in by water, air currents, animals (bats, arthropods) and humans [1, $6,7]$. According to Ogórek et al. [8, 9], the external environment and air currents have the main influence on number and species composition of airborne fungi in underground spaces. Most of the fungi are found in the twilight zone and in places situated near the entrances or ventilation shafts $[2-4,10]$.

Johnson et al. [11] isolated 42 fungi species from the wing membranes of hibernating bats, $73 \%$ of species belonging to class Ascomycota, $14 \%$ to Basidiomycota and $13 \%$ to Zygomycota. However, number, species composition and seasonal dynamics of airborne fungal associated with bats are still poorly known, especially in Europe. Many previous studies evidenced that other fungi, especially from Aspergillus and Penicillium group producing large numbers of spores, could be harmful for both animal and human health by causing mycosis and mycotoxicosis, allergies, dysfunction of the immune system and infections of internal organs (e.g. bone marrow, intestines, kidneys) as well as inflammations of the retina, lungs, peritoneum, and urethral system [12-14].

Currently, most studies are focused on $\mathrm{Pd}$, the pathogenic fungus causing white-nose syndrome (WNS), described as a widespread, epizootic disease affecting hibernating bats. WNS started in the north-eastern USA and Canada, is continuously spreading south and west and is associated with an unprecedented bat mortality exceeding 30-99 \% [15-19]. However, recent investigations confirmed the presence of this fungus, but without associated mass mortality, in fifteen countries: Austria, Belgium, Switzerland, Czech Republic, Germany, Denmark, Estonia, France, Hungary, Netherlands, Poland, Romania, Slovakia, Turkey and Ukraine [18, 20-22].

Underground corridors of the central sector of the Międzyrzecz Fortified Front (MFF) in Western Poland form the eighth largest bat hibernation site in the European Union, protected as Natura 2000 site "Nietoperek" and are closed to visitors during hibernation period, i.e. from 15th October to 15th April. The maximal bat number, 38,594 individuals of 10 species, with the predomination of species from genus Myotis was recorded there in January 2015 [23]. In Europe, eight species of Myotis have been observed being colonised by Pd: Myotis myotis, Myotis blythii, Myotis mystacinus, Myotis daubentonii, Myotis dasycneme, Myotis nattereri, Myotis bechsteinii and Myotis brandtii [18], and all of them, except $M$. blythii and $M$. brandtii, occur in large numbers in the Nietoperek. Such high density of hibernating bats could put them in danger of fungal infections, especially by Pd. Until now, the only case of presence of that fungal pathogen from Poland was recorded in 2010 on M. myotis in the southern part of the country [18]. Additionally, a study made in Nietoperek in January 2010-2012 by sampling of fungi from bats' muzzles using Scotch tape and microscopic examining of the spores (Kokurewicz T., Wibbelt G., Rachwald A., Schofield H., Glover A., Duverge L., Haddow J., Whitby D., Hargreaves
D., pers. observations) did not prove the presence of $\mathrm{Pd}$. Since 1999 in Nietoperek, the total number of bats has been constantly increasing. An exception to this trend is the number of Daubenton's bat (M. daubentonii) [24-26]. In the years 1999-2013, a statistically significant population decline of that species was recorded [27]. It is still unclear if these trends could be caused by lack of $\mathrm{Pd}$ in that hibernation site, or that the pathogenic fungus is present there but has no impact on bat population numbers, possibly apart from Daubenton's bat.

The aims of the study were (1) to determine the fungal species composition and changes during hibernation season in relation to bat number and microclimatic conditions and (2) evaluate the potential threat of fungi for bat assemblages and humans visiting the complex.

\section{Material and Methods}

\section{Study Area}

The study was done in the underground corridors of the central sector of the Miedzyrzecz Fortified Front (MFF) (52 $25^{\circ}$ N, $15^{\circ} 32^{\prime}$ E) in Western Poland (Fig. 1). The MFF was built by the Germans in the 1930s during World War II and consists of above ground bunkers connected by underground railway tunnels of total length of ca. $32 \mathrm{~km}$ located ca. 20-30 m underground [28]. In November 2007, the underground system with the surrounding surface area of 7377.37 ha became protected as Natura 2000 site Nietoperek (area code PLH080003). The targets of protection in MFF are four bats species, i.e. M. myotis, Barbastella barbastellus, $M$. dasycneme and M. bechsteinii mentioned in Annex II of the EC Directive 92/43/EEC of 21 May 1992 on the Conservation of Natural Habitats and of Wild Fauna and Flora (http://ec.europa.eu/environment/nature/legislation/ habitatsdirective/index_en.htm) and hibernating there in large numbers.

\section{Bat Monitoring}

For long-term monitoring of bat numbers, the underground system was divided into nine main sections [26]. The present study was undertaken in the sections 7 and 8 in the central part on the MFF (Fig. 1). Sections 7.9.1, 7.8 and 7.11.1 were available for tourists in winter, contrary to sections 7.1, 7.2 and 7.4.1 where human access was forbidden during hibernation season (Fig. 1). Bats were visually counted and identified to the species in nine sections of corridors where mycological observations were carried out. Due to legal reasons, bats were not counted in study sites 11 and 12, and consequently, those sites were excluded from analysis of relationship between bats and fungi. Because of difficulties in species identification without handling whiskered bat (M. mystacinus) and 
Fig. 1 "Nietoperek" bat reserve in Western Poland. a Geographic location. $\mathbf{b}$ The outline of the underground fortification system. c Study sites and sections (7.18.3) where bats assemblages were recorded in November 2013 and January and March 2014. E entrance, from 1 to 12 fungal sampling points ( 1 outside the underground system, from 2 to 12 inside the underground), $\mathrm{Lg}$ places were temperature/relative humidity data loggers were installed, $P z W$ panzerwerk, bunker, Bhf "Bahnhof," railway station

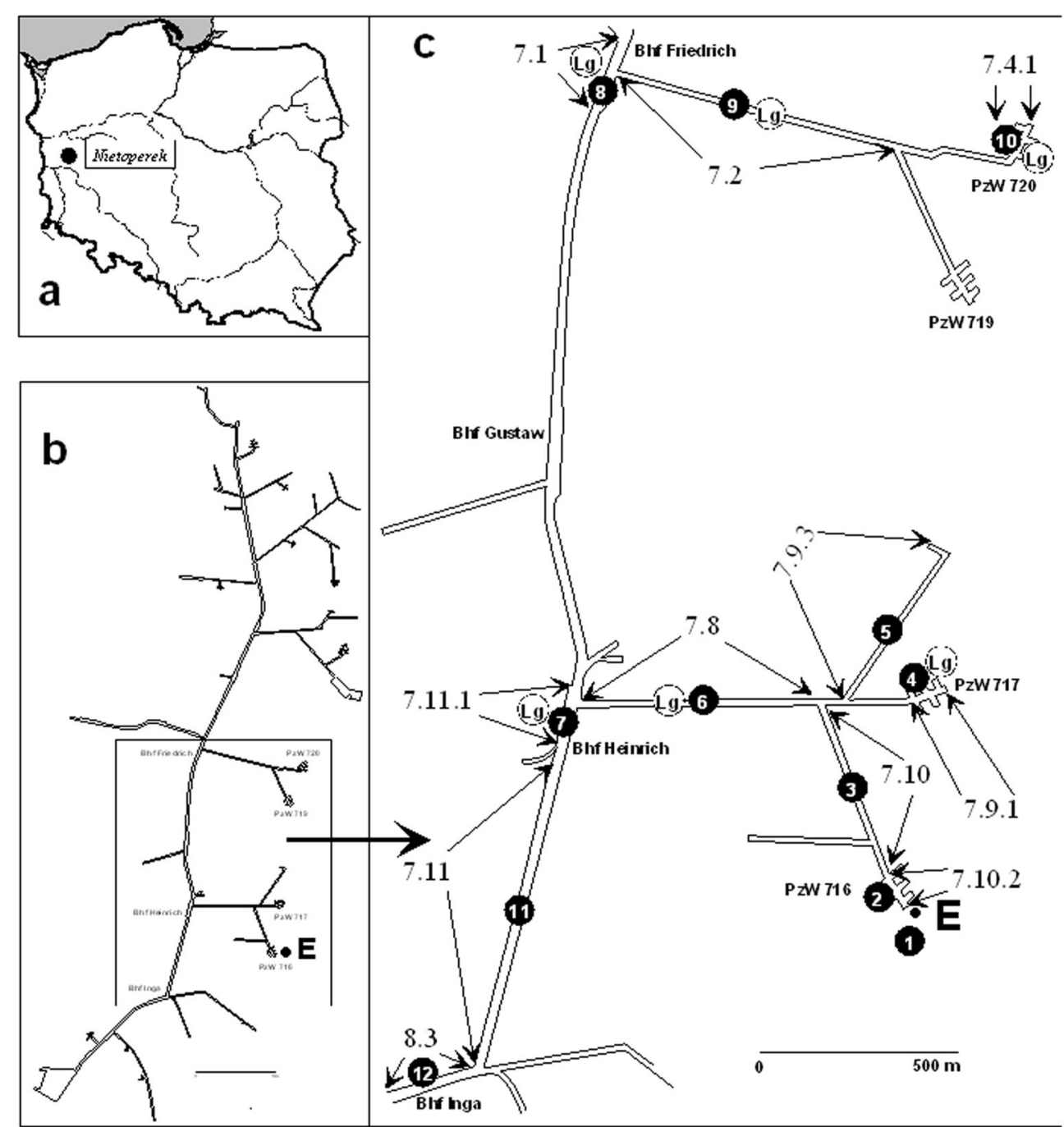

Brandt's bat ( $M$. brandtii), they were recorded as M. mystacinus and M. brandtii group (Fig. 2, Table 1). The observations were made under the licence issued by Nature Conservancy Management in Gorzów Wielkopolski.

\section{Microclimatic Parameter Measurement}

Ambient temperature $\left(T_{\mathrm{a}}\right)$ and relative humidity $(\mathrm{RH})$ were collected during the observation period (November-March) by use of automatic data loggers (Dallas IButton, Model DS1923, Dallas Semiconductors, TX, USA), accuracy: $\pm 0.5^{\circ} \mathrm{C}, \pm 5 \%$ RH. Six data loggers were placed in study sites where fungi were sampled, with the programmed sampling interval of $8 \mathrm{~h}$ (Fig. 1, Table 2). In the places where the loggers were not installed, the air temperature and relative humidity were measured during the study period by use of thermohygrometer LB-522 (LAB-EL), accuracy: $\pm 0.1{ }^{\circ} \mathrm{C}$, $\pm 2 \% \mathrm{RH}$.

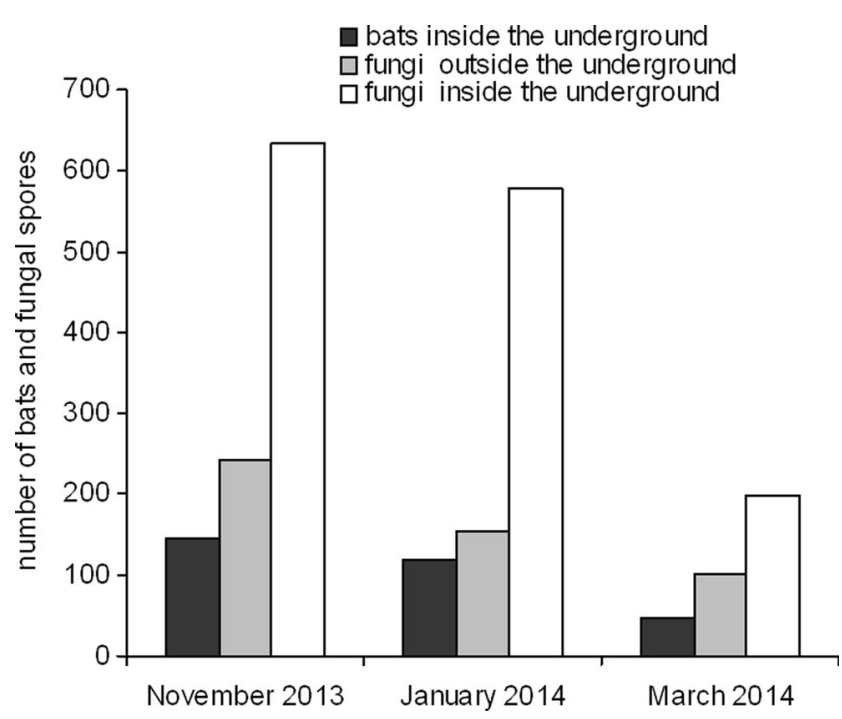

Fig. 2 The average number of bats (individuals) and airborne fungal spores (CFU/1 $\mathrm{m}^{3}$ of air) recorded inside and outside the "Nietoperek" underground 
Table 1 The numbers of fungi (CFU/1 $\mathrm{m}^{3}$ - colony-forming unit per $1 \mathrm{~m}^{3}$ of air) of

Pseudogymnoascus destructans $(\mathrm{Pd})$ and numbers of individuals of bat species occurring in

"Nietoperek" underground in

November 2013 (XI), January

2014 (I) and March 2014 (III)

\begin{tabular}{|c|c|c|c|c|c|c|c|c|c|c|}
\hline \multirow{2}{*}{$\begin{array}{l}\text { Pd or bad species/observation } \\
\text { periods }\end{array}$} & \multicolumn{9}{|c|}{ Study site number/Pd or bat number } & \multirow{2}{*}{$\begin{array}{l}\text { Total number } \\
\text { of individuals }\end{array}$} \\
\hline & 2 & 3 & 4 & 5 & 6 & 7 & 8 & 9 & 10 & \\
\hline \multicolumn{11}{|l|}{ Pseudogymnoascus destructans } \\
\hline $\mathrm{XI}$ & & & & & 1 & & 9 & 17 & 2 & 29 \\
\hline I & & 1 & & 9 & & & 3 & 17 & 3 & $\begin{array}{l}33(+1 \text { in study site } \\
12)\end{array}$ \\
\hline III & & & & & & & & & & 0 \\
\hline \multicolumn{11}{|l|}{ Myotis myotis } \\
\hline XI & 14 & 9 & & 45 & 16 & 29 & 275 & 387 & 102 & 877 \\
\hline I & 25 & 2 & & 19 & 8 & 5 & 160 & 383 & 16 & 618 \\
\hline III & 20 & & & 3 & 1 & & 69 & 196 & 2 & 291 \\
\hline \multicolumn{11}{|l|}{ Myotis daubentonii } \\
\hline $\mathrm{XI}$ & 20 & 9 & 5 & 45 & 8 & 15 & 58 & 40 & 27 & 227 \\
\hline I & 27 & & 2 & 63 & 1 & 6 & 50 & 23 & 17 & 189 \\
\hline III & 7 & & & 17 & & 1 & 18 & 12 & 10 & 65 \\
\hline \multicolumn{11}{|l|}{ Myotis nattereri } \\
\hline XI & 1 & & 1 & 3 & & 4 & 15 & 6 & 10 & 40 \\
\hline I & 17 & & 11 & 28 & & 7 & 41 & 12 & 9 & 125 \\
\hline III & & & & & & & & 1 & 3 & 4 \\
\hline \multicolumn{11}{|l|}{ Myotis mystacinus/Myotis brandtii } \\
\hline XI & & & & & & 1 & & & & 1 \\
\hline \multicolumn{11}{|l|}{ Myotis bechsteinii } \\
\hline $\mathrm{XI}$ & & & & & & & 1 & & & 1 \\
\hline I & & & & & & & 1 & & & 1 \\
\hline \multicolumn{11}{|l|}{ Myotis dasycneme } \\
\hline $\mathrm{XI}$ & & & & & & & 2 & & & 2 \\
\hline I & & & & & & & 1 & & & 1 \\
\hline III & & & & & & & 1 & & & 1 \\
\hline \multicolumn{11}{|l|}{ Barbastella barbastellus } \\
\hline I & & & & & & 1 & & & & 1 \\
\hline \multicolumn{11}{|l|}{ Plecotus auritus } \\
\hline $\mathrm{XI}$ & & & 2 & 1 & & 1 & 7 & 3 & 1 & 15 \\
\hline I & & & 1 & 1 & 1 & 1 & 10 & 5 & 1 & 20 \\
\hline \multicolumn{11}{|l|}{ Eptesicus serotinus } \\
\hline III & & & & & & & 1 & & & 1 \\
\hline \multicolumn{11}{|l|}{ Not determined to species (Indet.) } \\
\hline $\mathrm{XI}$ & & & & 3 & & & 1 & & & 4 \\
\hline I & & & & & & & 1 & & & 1 \\
\hline III & & & & & & & 3 & & 1 & 4 \\
\hline
\end{tabular}

\section{Mycological Evaluation of the Air and Fungal Identification}

The samples were collected in the beginning, middle and end of hibernation period, i.e. on the 9th November 2013, 17th January 2014 and 15th March 2014, in 12 study sites, one outside near the entrance and 11 inside the underground fortification system (Fig. 1, Table 3). The collision method with Air Ideal 3P sampler (bioMérieux) and Potato Dextrose Agar (PDA, Biocorp) medium were used for the isolation of fungi from the air. The air sampler was programmed for air sample volumes of 50, 100 and 150 L. Measurement in every study site was performed in six replicates for each volume. The sampler was positioned $1.5 \mathrm{~m}$ above the level of the floor. The incubation of the cultures was carried out at $15^{\circ} \mathrm{C}$ and room temperature $\left(25^{\circ} \mathrm{C}\right)$ for 4-42 days in darkness.

Generally, specific identification of the sampled fungi was performed using macro- and microscopic observations, namely the morphology of hyphae, conidia and sporangia, of the colonies that grew on PDA. Additionally, for macro-morphological 
Table 2 Study sites and an average of all three sampling times microclimatic conditions in studied parts of "Nietoperek" underground

\begin{tabular}{|c|c|c|c|c|}
\hline $\begin{array}{l}\text { Study site } \\
\text { number }\end{array}$ & Name & Section & $\begin{array}{l}\text { temperature } \\
\left({ }^{\circ} \mathrm{C}\right) \chi, \mathrm{LQ}-\mathrm{UQ}, \\
\min -\max , n\end{array}$ & $\begin{array}{l}\text { Relative } \\
\text { humidity } \\
(\%) \chi, \text { LQ-UQ, } \\
\text { min-max, } n\end{array}$ \\
\hline 2. & PzW 716 & 7.10 .2 & $\begin{array}{l}9.1 \\
9.1-9.1 \\
8.9-9.3 \\
9\end{array}$ & $\begin{array}{l}71.1 \\
70.0-71.1 \\
68.0-72.0 \\
9\end{array}$ \\
\hline 3. & $\begin{array}{l}\text { Corridor from } \\
\text { PzW } 716 \text { to } \\
\text { PzW } 717\end{array}$ & 7.10 & $\begin{array}{l}9.5 \\
9.4-9.6 \\
9.0-9.8 \\
9\end{array}$ & $\begin{array}{l}75.5 \\
74.0-76.0 \\
72.0-78.0 \\
9\end{array}$ \\
\hline 4. & PzW 717 & 7.9 .1 & $\begin{array}{l}9.8 \\
9.7-9.9 \\
9.6-9.9 \\
381\end{array}$ & $\begin{array}{l}75.2 \\
67.8-79.5 \\
47.1-95.0 \\
381\end{array}$ \\
\hline 5. & $\begin{array}{l}\text { Blind corridor } \\
\text { "Gallery" }\end{array}$ & 7.9 .3 & $\begin{array}{l}9.1 \\
9.1-9.2 \\
8.9-9.3 \\
9\end{array}$ & $\begin{array}{l}75.3 \\
74.0-76.0 \\
72.0-78.0 \\
9\end{array}$ \\
\hline 6. & $\begin{array}{l}\text { From "Gallery" } \\
\text { to Bhf } \\
\text { Heinrich }\end{array}$ & 7.8 & $\begin{array}{l}9.4 \\
9.3-9.5 \\
9.2-10.4 \\
381\end{array}$ & $\begin{array}{l}92.0 \\
89.2-100.0 \\
84.4-100.0 \\
381\end{array}$ \\
\hline 7. & Bhf Heinrich & 7.11 .1 & $\begin{array}{l}9.6 \\
9.4-9.9 \\
9.2-10.4 \\
381\end{array}$ & $\begin{array}{l}76.2 \\
67.0-78.4 \\
48.1-92.6 \\
381\end{array}$ \\
\hline 8. & Bhf Friedrich & 7.1 & $\begin{array}{l}8.1 \\
7.7-8.4 \\
7.4-8.7 \\
381\end{array}$ & $\begin{array}{l}100.0 \\
99.2-100.0 \\
68.7-100.0 \\
381\end{array}$ \\
\hline 9. & $\begin{array}{l}\text { From Bhf } \\
\quad \text { Friedrich } \\
\text { to PzW } 720\end{array}$ & 7.2 & $\begin{array}{l}8.7 \\
8.2-9.4 \\
6.1-9.9 \\
381\end{array}$ & $\begin{array}{l}100.0 \\
97.0-100.0 \\
77.5-100.0 \\
381\end{array}$ \\
\hline 10. & PzW 720 & 7.4 .1 & $\begin{array}{l}8.6 \\
7.7-9.1 \\
5.4-9.6 \\
381\end{array}$ & $\begin{array}{l}100.0 \\
98.8-100.0 \\
67.6-100.0 \\
381\end{array}$ \\
\hline 11. & $\begin{array}{l}\text { GDR from } \\
\text { Bhf Heinrich } \\
\text { to Bhf Inga }\end{array}$ & 7.11 & $\begin{array}{l}9.1 \\
9.0-9.2 \\
8.8-9.4 \\
9\end{array}$ & $\begin{array}{l}98.1 \\
97.0-98,1 \\
95.0-100.0 \\
9\end{array}$ \\
\hline 12. & Bhf Inga & 8.3 & $\begin{array}{l}9.2 \\
9.1-9.3 \\
8.9-9.5 \\
9\end{array}$ & $\begin{array}{l}85.1 \\
85.0-86.0 \\
83.0-88.0 \\
9\end{array}$ \\
\hline
\end{tabular}

$P z W$ (panzerwerk) bunker, Bhf (Bahnhof) railway station, GDR main road in the underground from north to south, $x$ median, $L Q-U Q$ lower and upper quartile, min-max minimal and maximal values, $n$ sample size

observations of fungal, species of the genus Penicillium and Aspergillus were used the following mediums: PDA, CzapekDox agar (1.2\% agar, Biocorp), Czapek Yeast Autolysate agar (CYA), Malt Extract agar (MEA), Yeast Extract Sucrose agar (YES), Dichloran $18 \%$ Glycerol agar (DG18), Oatmeal agar (OA) and Creatine agar (CREA) [29]. The isolates of Penicillium and Aspergillus were inoculated on each plate of each medium and incubated at $25^{\circ} \mathrm{C}$ (additional CYA plates were incubated at 30,33 and $37^{\circ} \mathrm{C}$ ) in the dark, for 7 days. For micromorphological observations, all fungi, microscopic mounts, were made in lactic acid from PDA, or MEA and DG18 colonies. Alcohol was used to remove excess conidia and prevent air bubbles. The fungi were identified using by diagnostic keys and monographs [30-38] for the filamentous fungi and diagnostic key and monographs [39, 40] for the yeast-like fungi.

\section{Statistical Analysis}

Normality of distribution of ambient temperature $\left(T_{\mathrm{a}}\right)$ and relative humidity $(\mathrm{RH})$ was tested by the use of Shapiro-Wilk's $W$ test. For parameters with distribution significantly different from normal $(P>0.05)$, the medians $(\chi)$ lower quartile (LQ) and upper quartile (UQ) were calculated, and the minimum and maximum values (range) and sample size $(n)$ were presented. The Pearson $(r)$ correlation coefficient and regression equation (least squares, model I) was calculated to investigate the relationships between number of bats and number of fungi spores in the nine study sites (2-10) situated in the undergrounds, where bats were present. Calculations were performed by the use of Statistica ver. 9.0 (StatSoft, Inc. (2009). STATISTICA data analysis software system, 9.0. www.statsoft.com).

\section{Results}

The presence of 9 bat taxa and 34 of airborne fungi (32 filamentous fungi and 2 yeasts) was recorded in the total study period (Tables 3, 4 and 5). The number of bats was highest in November (1167 individuals of 7 taxa), slightly reduced in January (956 individuals of 7 taxa) and dropped to the lowest number in March (366 individuals of 5 taxa)-Table 1. The largest numbers of fungi species (34) as well as the highest number of spores were observed in the underground in November (628.5 CFU/1 $\mathrm{m}^{3}$ of air); in January, species number remained the same; but number of spores slightly declined (579.4 CFU/1 $\mathrm{m}^{3}$ of air), while in March 2014, a strong decline down to 12 taxa and $199.4 \mathrm{CFU} / 1 \mathrm{~m}^{3}$ air was observed (Tables 3, 4 and 5, Fig. 2).

The highest numbers of bats during all inspections were recorded in study site 9, where the mouse-eared bat (M. myotis) was the most numerous species in all three observation periods exceeding 387 individuals in November and 196 in March (Fig. 1, Table 1). In that location, during all inspections, we also observed the largest number of fungal spores reaching the highest number in November (1198 CFU/1 $\mathrm{m}^{3}$ of air), remaining high in January (1136 CFU/1 $\mathrm{m}^{3}$ of air) and significantly declining in March down to $321 \mathrm{CFU} / 1 \mathrm{~m}^{3}$ of air (Tables 3, 4 and 5, Fig. 3). In the above ground reference study site (Fig. 1), much lower number of fungi species (20 during all three inspections) and 
Table 3 The total and average number of airborne fungi isolated in "Nietoperek" underground (CFU/1 $\mathrm{m}^{3}$ of air) in November 2013

\begin{tabular}{|c|c|c|c|c|c|c|c|c|c|c|c|c|c|}
\hline \multirow[t]{2}{*}{ Fungal species } & \multicolumn{12}{|c|}{ Study site number } & \multirow[t]{2}{*}{ Means } \\
\hline & 1 & 2 & 3 & 4 & 5 & 6 & 7 & 8 & 9 & 10 & 11 & 12 & \\
\hline Absidia glauca & 0 & 1 & 0 & 0 & 0 & 1 & 0 & 17 & 64 & 0 & 0 & 7 & 8.2 \\
\hline Alternaria alternata complex & 17 & 87 & 0 & 16 & 8 & 2 & 43 & 98 & 50 & 66 & 14 & 43 & 38.8 \\
\hline Alternaria botrytis & 0 & 0 & 0 & 0 & 3 & 0 & 6 & 0 & 0 & 13 & 0 & 1 & 2.1 \\
\hline Aspergillus sp. section Nigri & 6 & 8 & 0 & 5 & 0 & 3 & 17 & 43 & 0 & 1 & 0 & 2 & 7.2 \\
\hline Aspergillus sp. section Flavi & 0 & 0 & 2 & 0 & 7 & 0 & 11 & 0 & 13 & 0 & 0 & 0 & 3.0 \\
\hline Aspergillus sp. section Fumigati & 0 & 9 & 0 & 0 & 3 & 0 & 0 & 34 & 46 & 6 & 0 & 0 & 8.9 \\
\hline Aspergillus sp. 1 section Circumdati & 0 & 47 & 12 & 0 & 0 & 8 & 17 & 0 & 0 & 0 & 0 & 12 & 8.7 \\
\hline Aspergillus sp. 2 section Circumdati & 3 & 12 & 43 & 0 & 0 & 0 & 23 & 115 & 0 & 0 & 0 & 0 & 17.5 \\
\hline Candida albicans & 0 & 0 & 0 & 0 & 0 & 0 & 3 & 0 & 32 & 82 & 0 & 1 & 10.7 \\
\hline Chaetomium globosum complex & 0 & 13 & 0 & 0 & 0 & 0 & 0 & 11 & 52 & 2 & 0 & 0 & 7.1 \\
\hline Cladosporium cladosporioides complex & 78 & 354 & 211 & 149 & 34 & 27 & 189 & 265 & 188 & 103 & 124 & 169 & 164.8 \\
\hline Cladosporium herbarum complex & 5 & 0 & 9 & 0 & 3 & 1 & 32 & 0 & 17 & 10 & 0 & 17 & 8.1 \\
\hline Clonostachys rosea & 8 & 11 & 0 & 0 & 1 & 3 & 0 & 89 & 18 & 0 & 2 & 0 & 11.3 \\
\hline Fusarium oxysporum complex & 28 & 0 & 6 & 0 & 0 & 0 & 0 & 0 & 0 & 0 & 0 & 0 & 0.5 \\
\hline Mucor flavus & 0 & 0 & 0 & 0 & 0 & 0 & 6 & 4 & 0 & 0 & 0 & 13 & 2.1 \\
\hline Mucor hiemalis & 9 & 84 & 0 & 7 & 11 & 5 & 3 & 67 & 56 & 32 & 8 & 3 & 25.1 \\
\hline Mucor luteus & 0 & 0 & 0 & 2 & 0 & 0 & 0 & 8 & 13 & 1 & 8 & 0 & 2.9 \\
\hline Mucor racemosus & 0 & 0 & 18 & 0 & 0 & 0 & 0 & 20 & 43 & 22 & 23 & 28 & 14.0 \\
\hline Paecilomyces fumosoroseus & 0 & 0 & 0 & 0 & 3 & 0 & 23 & 5 & 43 & 13 & 0 & 7 & 8.5 \\
\hline Paecilomyces variotii complex & 0 & 0 & 32 & 0 & 0 & 11 & 0 & 53 & 68 & 3 & 0 & 13 & 16.4 \\
\hline Penicillium sp. 1 section Chrysogena & 43 & 203 & 115 & 296 & 73 & 52 & 285 & 0 & 138 & 102 & 98 & 0 & 123.8 \\
\hline Penicillium sp. 2 section Chrysogena & 17 & 11 & 4 & 0 & 0 & 22 & 3 & 0 & 18 & 13 & 3 & 0 & 6.7 \\
\hline Penicillium sp. 3 section Chrysogena & 7 & 16 & 0 & 0 & 4 & 0 & 7 & 0 & 31 & 0 & 19 & 1 & 7.1 \\
\hline Penicillium sp. 1 section Citrina & 3 & 0 & 0 & 0 & 4 & 18 & 0 & 113 & 0 & 80 & 0 & 14 & 20.8 \\
\hline Penicillium sp. 2 section Citrina & 0 & 20 & 0 & 0 & 16 & 2 & 0 & 6 & 0 & 17 & 27 & 85 & 15.7 \\
\hline Penicillium sp. section Exilicaulis & 4 & 0 & 18 & 0 & 0 & 2 & 32 & 15 & 0 & 0 & 0 & 0 & 6.1 \\
\hline Phoma sp. & 0 & 0 & 0 & 6 & 0 & 0 & 0 & 23 & 6 & 0 & 0 & 0 & 3.2 \\
\hline Pseudogymnoascus destructans & 0 & 0 & 0 & 0 & 0 & 1 & 0 & 9 & 17 & 2 & 0 & 0 & 2.6 \\
\hline Rhizopus stolonifer & 0 & 48 & 0 & 2 & 17 & 5 & 0 & 0 & 82 & 0 & 0 & 1 & 14.1 \\
\hline Rhodotorula rubra & 0 & 0 & 0 & 0 & 0 & 2 & 19 & 17 & 36 & 7 & 0 & 0 & 7.4 \\
\hline Sarocladium strictum & 2 & 17 & 4 & 44 & 11 & 5 & 0 & 17 & 6 & 88 & 0 & 0 & 17.5 \\
\hline Trichoderma harzianum & 11 & 52 & 0 & 66 & 0 & 1 & 62 & 23 & 159 & 0 & 0 & 0 & 33.0 \\
\hline Non-sporulating white colonies & 1 & 15 & 0 & 2 & 0 & 16 & 0 & 13 & 2 & 0 & 0 & 1 & 4.5 \\
\hline Non-sporulating black colonies & 0 & 19 & 0 & 0 & 2 & 11 & 0 & 18 & 3 & 0 & 1 & 0 & 4.9 \\
\hline In total & 242 & 1027 & 474 & 595 & 200 & 198 & 781 & 1083 & 1201 & 663 & 327 & 418 & 633.4 \\
\hline
\end{tabular}

1 outside the underground, $2-12$ inside the underground

${ }^{\text {a }}$ Means of CFU $/ 1 \mathrm{~cm}^{3}$ of air for study side from 2 to 12 (inside the underground)

number of spores from 242 to 155 in November and January, and to $102 \mathrm{CFU} / 1 \mathrm{~m}^{3}$ of air in March, were recorded (Tables 3, 4 and 5).

We found an association between number of bats and the count of fungal spores-Fig. 2. The concentration of airborne fungi increased with the increase of bats number in the underground study sites. Highly statistically significant positive correlation was found between those two variables $(r=0.71$, d.f. $=1,25, P<0.0001 ; y=328.29+1.916 x)$-Fig. 3 .
Cladosporium cladosporioides complex was the most frequently isolated fungi from samples taken both outside and inside the underground in November; in January, it was found only in samples taken inside corridors. Penicillium sp. 1 from section Chrysogena was most frequently isolated from both places in March and from the outside samples in January (Tables 3, 4 and 5).

The spores of $\mathrm{Pd}$ were recorded only in November (29 CFU/1 $\mathrm{m}^{3}$ of air) and January (34 CFU/1 $\mathrm{m}^{3}$ of air) in 
Table 4 The total and average number of airborne fungi isolated in "Nietoperek" underground (CFU/1 $\mathrm{m}^{3}$ of air) in January 2014

\begin{tabular}{|c|c|c|c|c|c|c|c|c|c|c|c|c|c|}
\hline \multirow[t]{2}{*}{ Fungal species } & \multicolumn{12}{|c|}{ Study site number } & \multirow[t]{2}{*}{ Means ${ }^{\mathrm{a}}$} \\
\hline & 1 & 2 & 3 & 4 & 5 & 6 & 7 & 8 & 9 & 10 & 11 & 12 & \\
\hline Absidia glauca & 0 & 0 & 0 & 0 & 9 & 0 & 0 & 9 & 7 & 0 & 0 & 0 & 2.3 \\
\hline Alternaria alternata complex & 5 & 11 & 4 & 23 & 8 & 5 & 37 & 51 & 32 & 32 & 8 & 14 & 20.5 \\
\hline Alternaria botrytis & 12 & 0 & 0 & 2 & 3 & 11 & 0 & 19 & 0 & 7 & 0 & 0 & 3.8 \\
\hline Aspergillus sp. section Nigri & 0 & 2 & 0 & 17 & 0 & 0 & 17 & 4 & 2 & 0 & 0 & 0 & 3.8 \\
\hline Aspergillus sp. section Flavi & 0 & 0 & 0 & 0 & 7 & 0 & 11 & 32 & 13 & 0 & 0 & 0 & 5.7 \\
\hline Aspergillus sp. section Fumigati & 0 & 0 & 2 & 0 & 3 & 0 & 0 & 7 & 46 & 0 & 0 & 7 & 5.9 \\
\hline Aspergillus sp. 1 section Circumdati & 0 & 86 & 7 & 0 & 74 & 16 & 17 & 0 & 0 & 24 & 0 & 1 & 20.5 \\
\hline Aspergillus sp. 2 section Circumdati & 15 & 2 & 9 & 4 & 0 & 0 & 23 & 105 & 0 & 3 & 0 & 0 & 13.3 \\
\hline Candida albicans & 0 & 2 & 2 & 0 & 17 & 0 & 3 & 11 & 32 & 41 & 0 & 1 & 9.9 \\
\hline Chaetomium globosum complex & 0 & 0 & 11 & 0 & 0 & 0 & 0 & 4 & 52 & 6 & 0 & 0 & 6.6 \\
\hline Cladosporium cladosporioides complex & 17 & 246 & 164 & 58 & 274 & 43 & 113 & 235 & 188 & 136 & 104 & 108 & 151.7 \\
\hline Cladosporium herbarum complex & 0 & 2 & 0 & 0 & 3 & 1 & 10 & 6 & 17 & 0 & 0 & 7 & 4.2 \\
\hline Clonostachys rosea & 0 & 6 & 0 & 0 & 76 & 3 & 0 & 45 & 18 & 0 & 2 & 0 & 13.6 \\
\hline Fusarium oxysporum complex & 0 & 9 & 0 & 0 & 0 & 0 & 7 & 0 & 0 & 6 & 0 & 3 & 2.3 \\
\hline Mucor flavus & 1 & 0 & 0 & 0 & 0 & 0 & 0 & 5 & 0 & 0 & 0 & 1 & 0.5 \\
\hline Mucor hiemalis & 14 & 33 & 17 & 7 & 11 & 5 & 17 & 50 & 56 & 4 & 8 & 7 & 19.5 \\
\hline Mucor luteus & 0 & 11 & 11 & 2 & 0 & 0 & 0 & 16 & 13 & 1 & 0 & 0 & 4.9 \\
\hline Mucor racemosus & 0 & 16 & 2 & 0 & 0 & 0 & 0 & 7 & 43 & 19 & 0 & 0 & 7.9 \\
\hline Peacilomyces fumoroseus & 1 & 11 & 0 & 0 & 3 & 0 & 23 & 21 & 43 & 16 & 0 & 5 & 11.1 \\
\hline Peacilomyces variotii complex & 0 & 0 & 7 & 0 & 0 & 11 & 0 & 30 & 68 & 0 & 0 & 8 & 11.3 \\
\hline Penicillium sp. 1 section Chrysogena & 38 & 254 & 43 & 214 & 132 & 95 & 285 & 87 & 138 & 152 & 75 & 82 & 141.5 \\
\hline Penicillium sp. 2 section Chrysogena & 7 & 15 & 6 & 0 & 67 & 17 & 7 & 4 & 31 & 0 & 19 & 11 & 16.1 \\
\hline Penicillium sp. 3 section Chrysogena & 0 & 1 & 0 & 0 & 0 & 5 & 3 & 29 & 18 & 1 & 3 & 4 & 5.8 \\
\hline Penicillium sp. 1 section Citrina & 3 & 8 & 1 & 0 & 4 & 0 & 0 & 32 & 0 & 32 & 0 & 2 & 7.2 \\
\hline Penicillium sp. 2 section Citrina & 0 & 20 & 0 & 0 & 16 & 2 & 0 & 27 & 0 & 66 & 27 & 43 & 18.3 \\
\hline Penicillium sp. section Exilicaulis & 32 & 0 & 8 & 0 & 0 & 2 & 32 & 0 & 0 & 14 & 0 & 19 & 6.8 \\
\hline Phoma sp. & 0 & 0 & 0 & 6 & 12 & 0 & 0 & 0 & 6 & 3 & 0 & 0 & 2.5 \\
\hline Pseudogymnoascus destructans & 0 & 0 & 1 & 0 & 9 & 0 & 0 & 3 & 17 & 3 & 0 & 1 & 3.1 \\
\hline Rhizopus stolonifer & 0 & 5 & 0 & 2 & 2 & 5 & 0 & 0 & 82 & 1 & 0 & 0 & 8.8 \\
\hline Rhodotorula rubra & 0 & 0 & 1 & 0 & 17 & 2 & 13 & 5 & 36 & 2 & 0 & 8 & 7.6 \\
\hline Sarocladium strictum & 6 & 5 & 0 & 7 & 11 & 0 & 9 & 22 & 14 & 30 & 0 & 0 & 8.9 \\
\hline Trichoderma harzianum & 2 & 2 & 0 & 66 & 16 & 1 & 29 & 0 & 159 & 13 & 0 & 0 & 26.0 \\
\hline Non-sporulating white colonies & 2 & 5 & 0 & 2 & 0 & 16 & 0 & 0 & 2 & 0 & 10 & 1 & 3.3 \\
\hline Non-sporulating black colonies & 0 & 12 & 1 & 0 & 2 & 11 & 0 & 3 & 3 & 4 & 0 & 9 & 4.1 \\
\hline In total & 155 & 764 & 297 & 410 & 776 & 251 & 656 & 869 & 1136 & 616 & 256 & 342 & 579.4 \\
\hline
\end{tabular}

1 outside the underground, $2-12$ inside the underground

${ }^{\mathrm{a}}$ Means of $\mathrm{CFU} / 1 \mathrm{~cm}^{3}$ of air for study side from 2 to 12 (inside the underground)

study sites $3,5,6,8-10$ and 12 , but most of them (17 CFU/ $1 \mathrm{~m}^{3}$ of air) were found in study site 9 (Fig. 1), with the largest numbers of bats, mainly mouse-eared bat ( $M$. myotis), were recorded during all inspections (Table 1). The median temperature and relative humidity in study site 9 were $8.7^{\circ} \mathrm{C}$ (min$\left.\max 6.1-9.9{ }^{\circ} \mathrm{C}\right)$ and $100 \%$ (min-max $\left.77.5-100.0 \%\right)$ Table 2. In that part of the underground tourist movement is forbidden in winter, contrary to the sections 7.9.1, 7.8 and 7.11 .1 , it could be assumed that only bats are responsible for both transport and high number of spores of $\mathrm{Pd}$ in that section of tunnels.

Fungi from genera Aspergillus and Penicillium were the most numerous species group of airborne fungi isolated during all study periods. Aspergillus spp. were not observed in March but constituted from 7.1 to $8.5 \%$ of all spores recorded in November and January, while Penicillium spp. constituted $28.5 \%$ in November, $34.2 \%$ in January and $83.6 \%$ in March of all recorded CFU/1 $\mathrm{m}^{3}$ (Tables 3, 4 and 5). 
Table 5 The total and average number of airborne fungi isolated in "Nietoperek" underground (CFU/1 m of air) in March 2014

Fungal species

Study site number

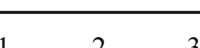

Means $^{\mathrm{a}}$

\begin{tabular}{|c|c|c|c|c|c|c|c|c|c|c|c|c|c|}
\hline Alternaria alternata complex & 0 & 0 & 0 & 0 & 0 & 0 & 5 & 0 & 0 & 0 & 0 & 0 & 0.5 \\
\hline Alternaria botrytis & 0 & 0 & 0 & 5 & 0 & 40 & 0 & 0 & 0 & 5 & 0 & 0 & 4.5 \\
\hline Cladosporium cladosporioides complex & 0 & 30 & 4 & 4 & 0 & 11 & 4 & 0 & 21 & 2 & 20 & 0 & 8.7 \\
\hline Cladosporium herbarum complex & 30 & 10 & 20 & 0 & 0 & 0 & 30 & 5 & 5 & 5 & 0 & 20 & 8.6 \\
\hline Mucor flavus & 0 & 0 & 0 & 0 & 0 & 0 & 0 & 5 & 0 & 0 & 0 & 0 & 0.5 \\
\hline Mucor hiemalis & 0 & 0 & 10 & 0 & 0 & 0 & 0 & 0 & 0 & 0 & 0 & 0 & 0.9 \\
\hline Peacilomyces fumoroseus & 0 & 0 & 0 & 0 & 10 & 0 & 0 & 0 & 0 & 0 & 0 & 0 & 0.9 \\
\hline Penicillium sp. 1 section Chrysogena & 40 & 45 & 60 & 125 & 0 & 100 & 90 & 110 & 225 & 60 & 120 & 165 & 100.0 \\
\hline Penicillium sp. 2 section Chrysogena & 2 & 0 & 0 & 0 & 0 & 0 & 0 & 0 & 0 & 0 & 0 & 0 & 0.0 \\
\hline Penicillium sp. section Citrina & 0 & 2 & 5 & 0 & 0 & 0 & 0 & 0 & 0 & 0 & 0 & 0 & 0.6 \\
\hline Penicillium sp. section Exilicaulis & 0 & 85 & 25 & 35 & 0 & 135 & 115 & 105 & 70 & 0 & 105 & 95 & 70.0 \\
\hline Phoma sp. & 5 & 0 & 0 & 0 & 0 & 0 & 0 & 0 & 0 & 0 & 0 & 0 & 0.0 \\
\hline Trichoderma harzianum & 0 & 0 & 0 & 1 & 0 & 0 & 0 & 0 & 0 & 0 & 30 & 2 & 3.0 \\
\hline Non-sporulating white colonies & 25 & 5 & 5 & 0 & 2 & 0 & 0 & 0 & 0 & 0 & 0 & 0 & 1.1 \\
\hline In total & 102 & 177 & 129 & 170 & 12 & 286 & 244 & 225 & 321 & 72 & 275 & 282 & 199.4 \\
\hline
\end{tabular}

1 outside the underground, 2-12 inside the underground

${ }^{\text {a }}$ Means of CFU $/ 1 \mathrm{~cm}^{3}$ of air for study side from 2 to 12 (inside the underground)

\section{Discussion}

According to the results of previous study, the most important factors affecting the survival of fungi are air temperature and humidity. Because of the presence of fungal spores in bioaerosols, their concentrations are the result of complex interactions between biological and environmental factors. Due to the dynamic nature of the atmosphere, the individual importance of each factor is hard to assess, especially in specific conditions observed underground [41]. However, according to many reports, the most important factors determining occurrence of fungal spores in underground spaces are airflow, the availability of organic matter and the conditions prevailing in the neighbouring external environment. Generally, larger numbers of fungi are isolated from air samples taken outside than inside underground sites $[2,3,8-10,42]$. Contrary to these results, during our study, most of the spores were isolated from the air samples taken inside the underground
Fig. 3 Relationship between number of bats and airborne fungal spores (CFU/1 $\mathrm{m}^{3}$ of air) in the nine study sites $(2-10)$ situated inside the "Nietoperek" underground. The Pearson correlation coefficient, statistical significance and regression equation are $r=0.71$, d.f. $=1,25$, $P<0.0001 ; y=328.29+1.916 x$

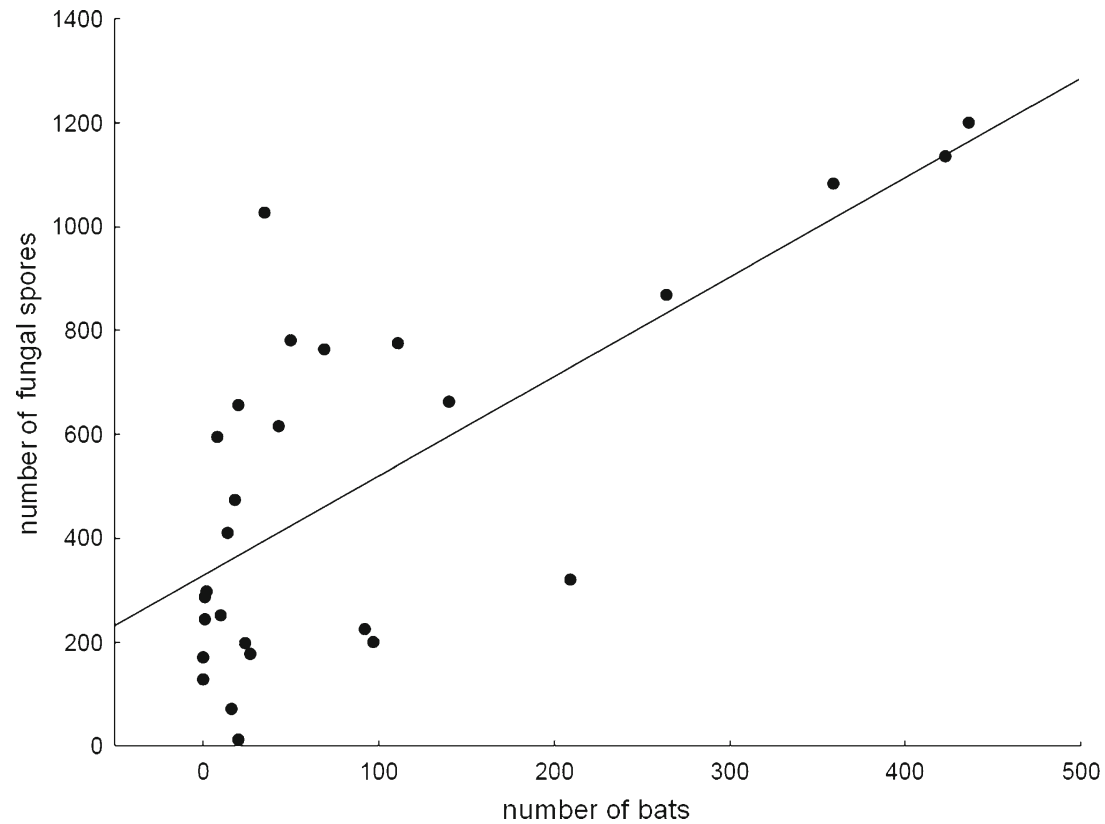


corridors. The results of previous study indicated that number and species composition of fungi was positively correlated with number of tourists and bats visiting underground [3, 43-48], which was confirmed by a positive relationship between number of bats and number of fungi spores in the air we found in our study site. In section 9, where the largest number of spores was recorded, the air movement, which could potentially transport the spores, runs from the entrance situated in section 7.4.1, whereas study plot 10 was situated the rear part of the underground corridors (Figs. 1 and 3). In study plot 10, the number of spores was lower than in section 9 (Fig. 3); moreover, in that part of the underground, tourist movement is forbidden in winter. Additionally, study plot 9 is situated ca. $750 \mathrm{~m}$ from the entrance and probably due to that no insects and other animals were recorded there during our study. Based on that, we can assume that bats may be one of the reasons for the increase in the number of spores in section 9 through the production of guano and the transport of spores from the external environment. According to Ogórek et al. [49], bat guano is a very good substrate for the development and survival of fungi inside underground sites, and it can also be a reservoir of fungi harmful to bats and humans.

Another aim of our study was to evaluate the risk of high concentrations of airborne fungi for human health. Some of the experts propose $5000 \mathrm{CFU}$ of fungi in $1 \mathrm{~m}^{3}$ of air as acceptable [50]. According to the Polish norm PN89/Z-04111/03 [51], the air can be not contaminated if it contains no more than $3000 \mathrm{CFU}$ of fungal spores in $1 \mathrm{~m}^{3}$, but on the other hand, the World Health Organization suggests that the concentration of airborne fungi as high as $1500 \mathrm{CFU}$ in $1 \mathrm{~m}^{3}$ air is acceptable, but only if it is a mixture of species [52]. The overall mean concentration of CFU found during our study was from 102 to 628.5 CFU/1 $\mathrm{m}^{3}$ in the air outside the underground and from 12 to 1198 inside of it. In other underground fortifications in Poland, similar concentrations of airborne fungi, e.g. from 245.5 to $1040.3 \mathrm{CFU}$ (Rzeczka complex), 92259 CFU (Osówka complex) and 25-1003 CFU (Włodarz complex), were recorded [2, 3, 9]. Summarising, the concentrations of airborne fungi in the Nietoperek bat reserve did not exceed official limits and norms for prevention of a health risk to humans.

In study site 9, where the largest number of Pd spores was detected (Figs. 1 and 3, Table 1), tourist movement does not occur in winter, which allows the assumption that only bats are responsible for both transport and growth of this fungal species in that section of the tunnels. In addition, microclimatic conditions in this area such as low temperatures and high relative humidity $\left(8.7^{\circ} \mathrm{C}, 100 \%\right)$ are favourable for the growth of $\mathrm{Pd}$ [17], and they are also preferred by hibernating mouse-eared bats (M. myotis) [53] and Daubenton's bats (M. daubentonii) [54], occurred in Nietoperek in large numbers (Table 1).
The lack of spores of Pd in March is contradictory to the results of a previous study indicating the highest numbers of that species towards the end of hibernation season, i.e. in March and April [18]. Our study showed that in November and January, when the number of bats and spores of Pd associated with them were high, it was possible to detect the presence of this species in Nietoperek, contrary to the low bat and spore numbers in March, which probably made it more difficult to detect the presence of that fungal species.

The study made in the Nietoperek underground during bat censuses in January 2010-2012 using a standard protocol of sampling of fungi from muzzles of bats by Scotch tape, followed by examination of spores under the microscope (Kokurewicz T., Wibbelt G., Rachwald A., Schofield H., Glover A., Duverge L., Haddow J., Whitby D., Hargreaves D., pers. observations) did not prove the presence of Pd. An additional factor which should be considered when applying this procedure is the sensitivity of hibernating bats to tactile disturbance [55] leading to additional energy loss [56]. Based on that future study directed at the influence of Pd on hibernating bat populations, we can recommend the method described above and tested during our study. Due to the easily repeatable sampling procedure and especially the low risk of harm to bats, we would recommend it as the first step, to be followed by more detailed investigation aimed at potential influence of Pd on hibernating bat populations, especially Daubenton's bat (M. daubentonii), a species declining in number in many localities in Europe.

Our study is the first aero-mycological evaluation being done in a large bat hibernation site aimed at describing the fungal species composition and its changes during hibernation season by using culture-based analysis and collision method. In this method, the suction force ensures adherence of all the fungal propagules to the surface of a suitable culture medium. Furthermore, we can accurately determine their number allocated to each volume of the air. This method is very fast, and a large number of samples can be easily taken during a short time period. Moreover, small air samplers, such as the Air Ideal 3P, are useful in difficult study conditions such as underground sites [57].

Currently, literature reported that $\mathrm{Pd}$ is transmitted with direct contact between bats or with contaminated environment bats such as soil and sediment [18, 19, 58]. Probably, this fungus can be also mechanically transmitted by adhesive spores and mycelium fragments on the body of ectoparasites such as spinturnicid mites [59]. We showed for the first time that the air can be also a reservoir of Pd, and it is likely that the fungus can be transmitted through the air. However, we do not know (1) the length of time the structure of this fungus retains its potential for propagation and to be infectious in the air and also (2) how many spores in the air are necessary to infect a bat. Therefore, further study of $\mathrm{Pd}$ in the air is necessary to find answers to the above 
questions. It seems that it will be particularly difficult to determine the relationship between an infection and the number of spores in the air, because the result of the infection depends on determinants of the pathogen, host(s) and the environment. Any changes in these determinants may trigger shifts in the complex host-pathogen system [60].

Penicillium from section Chrysogena, e.g. Penicillium chrysogenum and C. cladosporioides complex were the fungi species most frequently isolated from air samples taken from aboveground and underground study sites. Fungi of the genus Penicillium are cosmopolitan species able to produce spores in low temperatures observed in the underground, and these have been identified as important allergens in the indoor environment and as a rare causative agent of opportunistic mycosis in humans [61-67]. Fungi of the genus Cladosporium are also a cosmopolitan and common endophytic fungi [68, 69]. Additionally, studies of atmospheric air of various regions in Europe show that spores of Cladosporium spp. represent ca. $80 \%$ of all the caught spores, with the peak season for sporulation from June to September when several thousand spores are produced per cubic metre of air [70,71]. Cladosporium are very commonly isolated airborne fungi from the external and internal air of caves and other underground sites [2, 4, 8, 42].

The presence of toxic and allergenic fungi positively correlated in number with the number of bats should be considered when planning tourist movement in the underground spaces occupied by bats, such as Nietoperek bat reserve and many others. Based on our results, we suggest that veterinary examination of bats, and medical examination of bat workers and underground tourist guides, is necessary to find out more about the potential threat to bats and to public health also in other underground environments and wintering bats.

\section{Conclusions}

Our study is the first aero-mycological evaluation of a large bat hibernation site aimed at describing the fungal species composition and its changes during the hibernation season. Generally, the density of airborne fungi isolated from the underground air was higher than in the outdoor air samples but did not exceed official limits and norms established as dangerous for human health. We detected a positive relationship between number of bats and number of fungal spores underground. The large number of bats and the lack of tourists in the study sites with largest numbers of spores indicate that the presence of these animals appears to be the primary factor determining number and species composition of fungi in the underground sites. C. cladosporioides complex was the fungal species most frequently isolated from the air samples taken both outside and inside the underground system in November, but only from inside in January. Penicillium sp. 1 from section Chrysogena was most frequently isolated from both places in
March and from the outside in January. Microclimatic condition where Pd was found was preferred by hibernating $M$. myotis and $M$. daubentonii; therefore, these species are most probably especially prone to infection by this fungi species. In addition, the most frequently detected fungi genera were Aspergillus and Penicillium that can produce mycotoxins and cause infections. The collision method involving the Air Ideal 3P sampler and collecting spores on Petri dishes with appropriate solidified culture medium proved to be a good way to detect the fungi harmful to bats such as Pd. Moreover, sampling of airborne fungi is non-invasive, in contrast to direct examination of bats, and may be conducted at a time when bats are absent in hibernacula. Therefore, we recommend the use of this method as the first step in a mycological study of bat hibernation sites, to be followed by more detailed investigations aimed at recognising the potential influence of Pd on hibernating bat populations. The fungi species found in the underground can be pathogenic for human health and animals, especially for immunocompromised persons. In addition, we showed the first time that the air can be also a reservoir of $\mathrm{Pd}$, and it is likely that the fungus can be transmitted through the air. Therefore, further study of bats and people visiting the underground environment is necessary to find out more about the potential threat to these animals as well as to public health.

Acknowledgments We would like to thank MSc student team, Ewa Kwasiborska, Justyna Błesznowska, Laura Torrent Alsina, Michał Halewicz and Tomasz Marszałek; bat workers, Christiane Schmidt, Toni Bellstedt, Henry Schofield, John Haddow, Aneta Zapart and Grzegorz Apoznański and our bat friends, Katarzyna Kozyra, Dawid Zyskowski and Piotr Piliczewski for helping us during the field work. We are grateful to John Haddow for the first reading of the manuscript, critical remarks and language corrections. TK is very grateful to Dr. med.vet., MRCVS Gudrun Wibbelt from Leibniz-Institut für Zoo- und Wildtierforschung (Berlin, Germany) for providing the training course in microscopic identification of Pd spores.

Open Access This article is distributed under the terms of the Creative Commons Attribution 4.0 International License (http:// creativecommons.org/licenses/by/4.0/), which permits unrestricted use, distribution, and reproduction in any medium, provided you give appropriate credit to the original author(s) and the source, provide a link to the Creative Commons license, and indicate if changes were made.

\section{References}

1. Vanderwolf KJ, Malloch D, McAlpine DF, Forbes GJ (2013) A world review of fungi, yeasts, and slime molds in caves. Inter $\mathrm{J}$ Speleol 42(1):77-96, http://dx.doi.org/10.5038/1827-806X.42.1.9

2. Ogórek R, Pusz W, Lejman A, Uklańska-Pusz C (2014) Microclimate effects on number and distribution of fungi in the underground comlex in the Owl Mountains (Góry Sowie), Poland. J Cave Karst Stud 76(2):146-153. doi:10.4311/ 2013MB0123

3. Pusz W, Ogórek R, Uklańska-Pusz C, Zagożdżon P (2014) Speleomycological research in underground Osówka complex in 
Sowie Mountains (Lower Silesia, Poland). Int J Speleol 43(1):2734, http://dx.doi.org/10.5038/1827-806X.43.1.3

4. Pusz W, Ogórek R, Knapik R, Kozak B, Bujak H (2015) The occurrence of fungi in the recently discovered Jarkowicka cave in the Karkonosze Mts. (Poland). Geomicrobiol J 32(1):59-67. doi: 10.1080/01490451.2014.925010

5. Verant ML, Boyles JG, Waldrep W Jr, Wibbelt G, Blehert DS (2012) Temperature-dependent growth of Geomyces destructans, the fungus that causes bat white-nose syndrome. PLoS One 7(9): e46280. doi:10.1371/journal.pone.0046280

6. Chelius MK, Beresford G, Horton H, Quirk M, Selby G, Simpson RT, Horrocks R, Moore JC (2009) Impacts of alterations of organic inputs on the bacterial community within the sediments of Wind Cave, South Dakota, USA. Int J Speleol 38:1-10

7. Griffin DW, Gray MA, Lyles MB, Northup DE (2014) The transport of nonindigenous microorganisms into caves by human visitation: a case study at Carlsbad Caverns National Park. Geomicrobiol J 31(3):175-185. doi:10.1080/01490451.2013.815294

8. Ogórek R, Lejman A, Matkowski K (2014) Influence of the external environment on airborne fungi isolated from a cave. Pol $\mathrm{J}$ Environ Stud 23(2):435-440

9. Ogórek R, Pusz W, Matkowski K, Pląskowska E (2014) Assessment of abundance and species composition of filamentous fungi in the underground Rzeczka complex in Sowie Mountains (Lower Silesia, Poland). Geomicrobiol J 31(10):900-906. doi:10. 1080/01490451.2014.907380

10. Ogórek R, Lejman A, Matkowski K (2013) The fungi isolated from the Niedźwiedzia Cave in Kletno (Lower Silesia, Poland). Int J Speleol 42(2):161-166, http://dx.doi.org/10.5038/1827-806X.42.2.9

11. Johnson LJ, Miller AN, McCleery RA, McClanahan R, Kath JA, Lueschow S, Porras-Alfaro A (2013) Psychrophilic and psychrotolerant fungi on bats and the presence of Geomyces spp. on bat wings prior to the arrival of white nose syndrome. AEM 79(18):5465-5471. doi:10.1128/AEM.01429-13

12. Sweeney M, Dobson A (1998) Mycotoxin production by Aspergillus, Fusarium and Penicillium species. Int J Food Microbiol 43:141-158

13. Grajewski J, Twarożek M (2004) The healthy aspects of the influence of moulds and mycotoxins. Alergia 13:44-45

14. Jurado V, Laiz L, Rodriguez-Nava V, Boiron P, Hermosin B, Sanchez-Moral S, Saiz-Jimenez C (2010) Pathogenic and opportunistic microorganisms in caves. Int J Speleol 39:15-24

15. Turner GG, Reeder DM, Coleman JTH (2011) A five-year assessment of mortality and geographic spread of white-nose syndrome in North American bats and a look to the future. Bat Research News 52:13-27

16. Griggs A (2012) Enhanced surveillance for white-nose syndrome in bats. Em Inf Dis 18:530-532

17. Hayes MA (2012) The Geomyces fungi: ecology and distribution. BioScience 62(9):819-823

18. Puechmaille SJ, Wibbelt G, Korn V, Fuller H, Forget F, Mühldorfer K, Kurth A, Bogdanowicz W, Borel C, Bosch T, Cherezy T, Drebet M, Grul T, Haarsma A-J, Herhaus F, Hallart G, Hammer M, Jungmann C, Le Bris Y, Lutsar L, Masing M, Mulkens B, Passior K, Starrach M, Wojtaszewski A, Zöphel U, Teeling EC (2011) PanEuropean distribution of white-nose syndrome fungus (Geomyces destructans) not associated with mass mortality. PLoS One 6(4): e19167. doi:10.1371/journal.pone.0019167

19. Lorch JM, Muller LK, Russel RE, O'connor M, Linder DL, Bleher DS (2013) Distribution and environmental persistence of the causative agent of white-nose syndrome, Geomyces destructans, in bat hibernacula of the eastern United States. AEM 79(4):1293-1301

20. Puechmaille SJ, Verdeyroux P, Fuller H, Ar Gouilh M, Bekaert M, Teeling EC (2010) White-nose syndrome fungus (Geomyces destructans) in bat. France: Emerg Infect Dis 16:290-293. doi:10. 3201/eid1602.091391
21. Martínková N, Bačkor P, Bartonička T, Blažková P, Červený J, Falteisek L, Gaisler J, Hanzal V, Horáček D, Hubálek Z, Jahelková H, Kolařík M, Korytár L, Kubátová A, Lehotská B, Lehotský R, Lučan RK, Májek O, Matějů J, Řehák Z, Šafář J, Tájek P, Tkadlec E, Uhrin M, Wagner J, Weinfurtová D, Zima J, Zuka J, Horáček I (2010) Increasing incidence of Geomyces destructans fungus in bats from the Czech Republic and Slovakia. PLoS One 5:e13853. doi:10.1371/journal.pone.0013853

22. Wibbelt G, Kurth A, Hellmann D, Weishaar M, Barlow A, Veith M, Prüger J, Görföl T, Grosche L, Bontadina F, Zöphel U, Seidl H-P, Cryan PM, Blehert DS (2010) White-nose syndrome fungus (Geomyces destructans) in bats. Europe: Emerg Infect Dis 16: 1237-1242. doi:10.3201/eid1608.100002

23. Cichocki J, Stopczyński M, Bator A, Grzywiński W, Ignaczak M, Ignaszak K, Jaros R, Kowalski M, Łochyński M, Postawa T, Warchałowski M, Węgiel A, Wojtaszyn G (2015) Liczebność nietoperzy zimujących w rezerwacie Nietoperek w roku 2015 (The number of wintering bats in the reserve Nietoperek in 2015). In: Abstracts of XXIV Polish National Bat Conference, 13-15 November 2015, Kazimierz Dolny, Poland, pp 36-37 [in Polish]

24. Urbańczyk Z (1991) Rezerwat Nietoperek (Nietoperek reserve). Przyroda Ziemi Lubuskiej. Lubuski Klub Przyrodników, Świebodzin, p 24 [in Polish]

25. Rogowska K, Kokurewicz T (2007) The longest migrations of three bat species to the "Nietoperek" bat reserve (Western Poland). Berichte der Naturforschenden Gesellschaft der Oberlausitz, Supplement zu Band 15:53-60

26. Andrzejczak W, Batycki A, Kasprzak A, Kokurewicz T, Matraj M, Rusiński N, Świerkosz K, Wylęgała P, Weigle A, Kaim K (2009) Documentation of the management plan for the Natura 2000 site "Nietoperek" (PLH080003). National Foundation for Environmental Protection, Warszawa, p 250

27. Kokurewicz T, Bongers F, Ciechanowski M, Duvergè L, Glover A, Haddow J, Rachwald A, Rusiński M, Schmidt C, Schofield H, Wawrocka K, Willems W, Zapart A (2014) Bat research and conservation in "Nietoperek" bat reserve (Western Poland). Abstracts of the XIII European Bat Research Symposium, September 0105.2014, Šibenik, Croatia, pp 93-94

28. Woźniak C (1996) History and architecture of the undergrounds of the Międzyrzecki Rejon Umocniony. In: Kokurewicz T (ed) The nature of the Gorzow Voyvodeship. Bat reserve "Nietoperek". Voyvodeship Fund for Environment Protection and Water Management, Gorzow Wielkopolski, pp 78-113

29. Samson RA, Houbraken J, Frisvad JC (2010) Introduction to foodand airborne fungi, 7th edn. CBS-KNAW Fungal Biodiversity Centre, Utrecht

30. Simmons EG (2007) Alternaria: an identification manual. CBS Fungal Biodiversity Centre, Netherlands

31. Schubert K, Groenewald JZ, Braun U, Dijksterhuis J, Starink M, Hill CF, Zalar P, de Hoog GS, Crous PW (2007) Biodiversity in the Cladosporium herbarum complex (Davidiellaceae, Capnodiales), with standardisation of methods for Cladosporium taxonomy and diagnostics. Stud Mycol 58:105-156. doi:10.3114/sim.2007.58.05

32. Pitt JI, Hocking AD (2009) Fungi and food spoilage. Springer, New York

33. Bensch K, Groenewald JZ, Dijksterhuis J, Starink-Willemse M, Andersen B, Summerell BA, Shin H-D, Dugan FM, Schroers HJ, Braun U, Crous PW (2010) Species and ecological diversity within the Cladosporium cladosporioides complex (Davidiellaceae, Capnodiales). Stud Mycol 67:1-94. doi:10.3114/ $\operatorname{sim} .2010 .67 .01$

34. Chaturvedi V, Springer DJ, Behr MJ, Ramani R, Li X, Peck MK, Ren P, Bopp DJ, Wood B, Samsonoff WA, Butchkoski CM, Hicks AC, Stone WB, Rudd RJ, Chaturvedi S (2010) Morphological and molecular characterizations of psychrophilic fungus Geomyces destructans from New York bats with white-nose syndrome 
(WNS). PLoS One 5(5):e10783. doi:10.1371/journal.pone. 0010783

35. Houbraken J, Verweij PE, Rijs AJMM, Borman AM, Samson RA (2010) Identification of Paecilomyces variotii in clinical samples and setting. J Clin Microbiol 48(8):2754-2761

36. Watanabe T (2011) Pictorial atlas of soil and seed fungi: morphologies of cultured fungi and key to species. CRC press, USA

37. Visagie CM, Varga J, Houbraken J, Meijer M, Kocsubé S, Yilmaz N, Fotedar R, Seifert KA, Frisvad JC, Samson RA (2014) Ochratoxin production and taxonomy of the yellow aspergilli (Aspergillus section Circumdati). Stud Mycol 78:1-61. doi:10. 1016/j.simyco.2014.07.001

38. Visagie CM, Hirooka Y, Tanney JB, Whitfield E, Mwange K, Meijer M, Amend AS, Seifert KA, Samson RA (2014) Aspergillus, Penicillium and Talaromyces isolated from house dust samples collected around the word. Stud Mycol 78:63-139

39. Kurtzman CP, Fell W (1998) The yeasts, a taxonomic study, 4th edn. Elsevier, Amsterdam

40. Barnett JA, Payne RW, Yarrow D (2000) Yeasts: characteristics and identification, 3rd edn. Cambridge University Press, Cambridge

41. Grinn-Gofron A, Strzelczak A, Wolski T (2011) The relationships between air pollutants, meteorological parameters and concentration of airborne fungal spores. Environ Poll 159:602-608. doi:10. 1016/j.envpol.2010.10.002

42. Ogórek R, Višňovská Z, Tančinová D (2016) Mycobiota of underground habitats: case study of Harmanecká cave in Slovakia. Microb Ecol 71(1):87-99. doi:10.1007/s00248-015-0686-4

43. Hoyos M, Soler V, Cañaveras JC, Sánchez-Moral S, Sanz-Rubio E (1998) Microclimatic characterization of a karstic cave: human impact on microenvironmental parameters of a prehistoric rock art cave (Cándamo Cave, northern Spain). Environ Geol 33:231-242. doi: $10.1007 / \mathrm{s} 002540050242$

44. Gu JD (2003) Microbiological deterioration and degradation of synthetic polymeric materials: recent research advances. Intern Biodeter Biodegr 52:69-91, doi.org/10.1016/S0964-8305(02)00177-4

45. Li XS, Arai H, Shimoda I, Kuraishi H, Katayama Y (2008) Enumeration of sulfuroxidizing microorganisms on deteriorating stone of the Angkor monuments, Cambodia. Microbiol Environ 23:293-298

46. Fernández-Cortès AS, Cuezva S, Sanchez-Moral S, Caňaveras JC, Porca E, Jurado V, Martin-Sanchez PM, Saiz-Jimenez C (2011) Detection of human-induced environmental disturbances in a show cave. ESPR 18:1037-1045

47. Tsuneda A, Davey ML, Tsuneda I, Hudgins A, Currah RS (2011) Endophoma, a new didymellaceous endoconidial genus from batcave soil. Mycologia 103(5):1146-1155

48. Saiz-Jimènez C (2012) Microbiological and environmental issues in show caves. World J Microb Biot 28(7):2453-2464

49. Ogórek R, Dylag M, Kozak B, Višňovská Z, Tančinová D, Lejman A (2016) Fungi isolated and quantified from bat guano and air in Harmanecká and Driny Caves (Slovakia). J Cave and Karst Stud doi:10.4311/2015MB0108

50. Górny RL (2010) Aerozole biologiczne - rola normatywów higienicznych w ochronie środowiska i zdrowia (Biological aerosols $-\mathrm{A}$ role of hygienic standards in the protection of environment and health). Environ Med 13(1):41-51 [In Polish]

51. Pilarek M (1989) Polska Norma PN-89/Z-04111/03. Ochrona czystości powietrza. Badania mikrobiologiczne. Oznaczanie liczby grzybów mikroskopowych w powietrzu atmosferycznym (imisja) przy pobieraniu próbek metodą aspiracyjną i sedymentacyjną. (Polish Norm PN-89/Z-04111/03. Air purity protection. Microbiological testing. Determining the Concentration of Microscopic in the atmospheric air (immission) during the by
Aspiration and Sedimentation Sampling). Polski Komitet Normalizacji Miar i Jakości, Warszawa [in Polish]

52. Indoor Air Quality (1988) Biological contaminants (1988) report on a WHO meeting, Rautavaara, 29 August-2 September 1988: WHO Regional Publications, European Series no. 31. WHO Regional Office for Europe, Kopenhagan

53. Boratyński J, Rusiński M, Kokurewicz T, Bereszyński A, Wojciechowski MS (2012) Clustering behavior in wintering greater mouse-eared bats Myotis myotis - the effect of microenvironmental conditions. Acta Chiropt 4(2):417-424

54. Kokurewicz T (2004) Sex and age related habitat selection and mass dynamics of Daubenton's bats Myotis daubentonii (Kuhl, 1817) hibernating in natural conditions. Acta Chiropt 6:121-144

55. Speakman JR, Webb PI, Racey PA (1991) Effects of disturbance on the energy expenditure of hibernating bats. J Appl Ecol 28:10871104

56. Thomas DW, Dorais M, Bergeron JM (1990) Winter energy budgets and cost of arousals for hibernating little brown bats, Myotis lucifugus. J Mammal 71:475-479

57. Ogórek R, Lejman A (2015) Badania speleomikologiczne w wybranych obiektach podziemnego kompleksu Riese (Góry Sowie, Dolny Śląsk, Polska) / Speleomycological research in the selected objects of underground Riese complex (Sowie Mountains, Lower Silesia, Poland). Postep Mikrobiol 54(4): 344-353 [in Polsh]

58. Lindner DL, Gargas A, Lorch JM, Banik MT, Glaeser J, Kunz TH, Blehert DS (2011) DNA-based detection of the fungal pathogen Geomyces destructans in soil from bat hibernacula. Mycologia 103:241-246

59. Lučan RK, Bandouchova H, Bartonička T, Pikula J, Zahradníková JA, Zukal J, Martínková N (2016) Ectoparasites may serve as vectors for the white-nose syndrome fungus. Parasit Vectors 9:16. doi: 10.1186/s13071-016-1302-2

60. Zukal J, Bandouchova H, Brichta J, Cmokova A, Jaron KS, Kolarik M, Kovacova V, Kubátová A, Nováková A, Orlov O, Pikula J, Presetnik P, Šuba J, Zahradníková JA, Martínková N (2016) White-nose syndrome without borders: Pseudogymnoascus destructans infection tolerated in Europe and Palearctic Asia but not in North America. Sci Rep 6:19829. doi:10.1038/srep19829

61. Eschete ML, King JW, West BC, Oberle A (1981) Penicillium chrysogenum endophthalmitis: first reported case. Mycopathol 74: 125-127. doi:10.1007/BF01259468

62. Fergusson RJ, Milne LRJ, Crompton GK (1984) Penicillium allergic alveolitis: faulty installation of central heating. Thorax 39:294-298

63. Hoffman M, Bash E, Berger SA, Burke M, Yust I (1992) Fatal necrotizing esophagitis due to Penicillium chrysogenum in a patient with acquired immunodeficiency syndrome. Europ J Clin Microbiol Infec Dis 11:1158-1160

64. Chang JCS, Foarde KK, Vanosdell DW (1995) Growth evaluation of fungi (Penicillium and Aspergillus spp.) on ceiling tiles. Atmos Environ 29(17):2331-2337, http://dx.doi.org/10.1016/13522310(95)00062-4

65. Hunter CA, Lea RG (1995) The airborne fungal population of representative British homes. Air Qual Monographs 2:141-153

66. Sautour M, Rouget A, Dantigny P, Divies C, Bensoussan M (2004) Application of Doehlert design to determine the combined effects of temperature, water activity and $\mathrm{pH}$ on conidial germination of Penicillium chrysogenum. JAM 91:900-906

67. Samson RA, Yilmaz N, Houbraken J, Spierenburg H, Seifert KA, Peterson SW, Varga J, Frisvad JC (2011) Phylogeny and nomenclature of the genus Talaromyces and taxa accommodated in 
Penicillium subgenus Biverticillium. Stud Mycol 70(1):159-183. doi:10.3114/sim.2011.70.04

68. El-Morsy EM (2000) Fungi isolated from the endorhizosphere of halophytic plants from the Red Sea Coast of Egypt. Fungal Divers 5:43-54

69. Kumaresan V, Suryanarayanan TS (2002) Endophyte assemblage in young, mature and senescent leaves of Rhizophora apiculata: evidence for the role of endophytes in mangrove litter degeneration. Fungal Divers 9:81-91

70. D'Amato G, Spieksma FTM (1995) Aerobiologic and clinical aspects of mould allergy in Europe. Allergy 50:870-877. doi:10.1111/ j.1398-9995.1995.tb02492.x

71. Lipiec A (2000) Mould hypersensitivity in allergic rhinitis patients. In Rev Allergol Clin Immunol 6:2-3 